\title{
ATIVISMO JUDICIAL E CONSTRUÇÃO DO DIREITO CIVIL: ENTRE DOGMÁTICA E PRÁXIS
}

\author{
JUDICIAL ACTIVISM AND THE CONSTRUCTION OF PRIVATE LAW: \\ BETWEEN DOGMATIC AND PRAXIS \\ ACTIVISMO JUDICIAL Y CONSTRUCCIÓN DEL DERECHO CIVIL: ENTRE \\ DOGMÁTICA Y PRÁXIS
}

Gustavo Tepedino ${ }^{1}$

Licença CC BY:

Artigo distribuído sob os termos Creative Commons, permite uso e distribuição irrestrita em qualquer meio desde que o autor credite a fonte original.

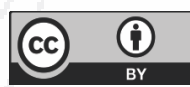

Resumo: O triunfo do constitucionalismo democrático e da doutrina da efetividade traz consigo um novo papel do intérprete. A magistratura, nesse contexto, possui a responsabilidade de concretizar, a partir da atividade jurisdicional, os valores e os fins constitucionais, o que, por vezes, poderá representar ativismo judicial, na medida em que se revelar necessário interferir na esfera de atuação dos demais poderes. A noção de ativismo, portanto, como ruptura do formalismo positivista, mostra-se benfazejo e alvissareiro método hermenêutico em prol da efetividade dos comandos constitucionais, contanto que se estabeleçam balizas predefinidas para a atuação do magistrado, evitando, assim, desequilíbrio na moldura institucional em que se assentam as democracias contemporâneas. $O$ artigo propõe, nessa linha, reflexão acerca do ativismo judicial na experiência brasileira. Procura-se ilustrar os perigos que se camuflam na adoção de técnica interpretativa conservadora na figura dos sete pecados capitais.

Palavras-chave: Constitucionalismo democrático; Teoria da interpretação; Ativismo judicial; Direito Civil.

1 Professor Titular de Direito Civil da Faculdade de Direito da Universidade do Estado do Rio de Janeiro - UERJ. Doutor em Direito Civil pela Universidade de Camerino, Itália (1986). Sócio fundador do escritório Gustavo Tepedino Advogados. E-mail: tepedino@uol.com.br. O autor agradece vivamente ao mestrando Francisco de Assis Viégas, da Faculdade de Direito da UERJ, pela colaboração na pesquisa desenvolvida e pela revisão do texto. 
Abstract: The triumph of democratic constitutionalism and the legal effectiveness of the Constitution brings a new role of the interpreter. The judiciary, in this context, has the responsibility to ensure the effectiveness of constitutional values and purposes, which may sometimes represent judicial activism, especially when it becomes necessary to interfere in the sphere of action of the other branches. Therefore, the notion of activism, so as rupture of positivist formalism, appears as a beneficent hermeneutical method in favor of the effectiveness of constitutional provisions, as long as pre-defined standards are established for the performance of the judge, avoiding imbalances in the institutional framework that is inherent to contemporary democracies. The article proposes a reflection on judicial activism in the Brazilian experience. The dangers hidden in the adoption of the conservative interpretative technique are illustrated in the figure of the seven deadly sins.

Keywords: Democratic constitutionalism; Hermeneutic theory; Judicial activism; Civil Code.

Resumen: El triunfo del constitucionalismo democrático y de la doctrina de la efectividad trae consigo un nuevo papel del intérprete. La magistratura, en este contexto, posee la responsabilidad de concretizar, a partir de la actividad jurisdiccional, los valores y los fines constitucionales, lo que, por veces, podrá representar activismo judicial, en la medida que se revela como necesario interferir en la esfera de actuación de los demás poderes. La noción de activismo, por tanto, como ruptura del formalismo positivista, se muestra benéfico y propicio método hermenéutico en prole de la efectividad de los comandos constitucionales, con que se establecen balizas predefinidas para la actuación del magistrado, evitando, así, desequilibrio en la moldura institucional en que se asientan las democracias contemporáneas. El artículo propone, en esta línea, una reflexión acerca del activismo judicial en la experiencia brasileña. Se busca ilustrar los peligros que se camuflan en la adopción de técnica interpretativa conservadora en la figura de los siete pecados capitales.

Palabras-clave: Constitucionalismo democrático; Teoría de la interpretación; Activismo judicial; Derecho Civil.

INTRODUÇÃO

Muito se tem debatido acerca das possibilidades e dos limites do que se tem designado, genericamente, como ativismo judicial. O fenômeno, que suscita intensa controvérsia, não pode ser tratado de maneira unitária e maniqueísta, ora como discurso sedicioso em favor de concepção política contrária ao ordenamento, ora como ardil antidemocrático a ser combatido. No tempo que passa, mostra-se notável a evolução do papel da magistratura, especialmente após a Constituição de 1988, que deflagrou o itinerário vitorioso da efetividade das normas constitucionais, notadamente nas relações privadas. ${ }^{2}$ A vetusta imagem, cunhada por Montesquieu, do juiz como "la bouche de la loi", encontrase definitivamente afastada da teoria da interpretação. ${ }^{3}$

2 Confira-se, acerca do significado hermenêutico da aproximação entre direito público e direito privado, TEPEDINO, Gustavo. Premissas Metodológicas para a Constitucionalização do Direito Civil. In: Temas de Direito Civil, t. I. 4. ed. Rio de Janeiro: Renovar, 2008, p. 20 e ss.

3 Já se destacou, nesta linha, o ocaso da subsunção na teoria da interpretação, tendo em vista que, "se o 
O novo papel da magistratura, contudo, longe de configurar tendência usurpadora da soberania popular, representa aspecto significativo do denominado constitucionalismo democrático, ${ }^{4}$ legitimado na experiência brasileira pela Constituição da República, no âmbito do qual o ativismo judicial permite a atuação jurisdicional direcionada à concretização dos valores e fins constitucionais, com interferência crescente no espaço de atuação dos demais Poderes. ${ }^{5}$ Os limites, portanto, dessa interferência é que devem ser objeto de reflexão por parte da teoria da interpretação, para que sejam estabelecidos critérios de preservação da segurança jurídica.

Nesta medida, a noção de ativismo, como ruptura do formalismo positivista, mostra-se benfazejo e alvissareiro método hermenêutico em prol da efetividade dos comandos constitucionais, especialmente levando-se em conta o ambiente de justiça transicional identificado pela doutrina constitucionalista no processo político brasileiro. ${ }^{6}$ Entretanto, a ausência de balizas predefinidas para a atuação

ordenamento é unitário, moldado na tensão dialética da argamassa única dos fatos e das normas, cada regra deve ser interpretada e aplicada a um só tempo, refletindo o conjunto das normas em vigor. A norma do caso concreto é definida pelas circunstâncias fáticas na qual incide, sendo extraída do conjunto normativo em que se constitui o ordenamento como um todo" (TEPEDINO, Gustavo. O ocaso da subsunção. Revista trimestral de direito civil, Rio de Janeiro, v. 34, abr.-jun./2008).

4 A expressão denota o reconhecimento de que a democracia não se esgota no respeito ao princípio majoritário, pressupondo antes o acatamento das regras do jogo democrático, as quais que incluem a garantia de diretos e garantias fundamentais previstos na Constituição da República, de modo a viabilizar efetiva participação igualitária do cidadão na esfera pública, com a indispensável tutela das minorias. Tal noção de democracia é comungada por grande parte dos teóricos contemporâneos. Por todos, v. HABERMAS, Jürgen. Popular sovereignty as procedure. In: BONHAM, James; REHG, William (Org.). Deliberative democracy. Cambridge, The MIT Press, 1997, p. 49: "Human rights do not compete with popular sovereignty; they are identical with the constitutive conditions of a self-limiting practice of publicly discursive will-formation. The separation of powers is then explained by the logic of application and supervised implementation of laws that have been enacted through such a process". Em tradução livre: "Direitos humanos não competem com soberania popular; eles são idênticos nas condições constitutivas da prática auto limitativa de formação da vontade publicamente discursiva. A separação dos poderes é então explicada pela lógica de aplicação e implementação supervisionada das leis que foram promulgadas por meio deste processo".

5 BARROSO, Luís Roberto. Judicialização, Ativismo Judicial e Legitimidade Democrática. In: COUTINHO, Jacinto Nelson de Miranda. FILHO, Roberto Fragale; LOBÃO, Ronaldo. Constituição e Ativismo Judicial: limites e possibilidades da norma constitucional e da decisão judicial. Rio de Janeiro: Lumen Juris, 2011, p. 279.

6 Sobre a complexa transição jurídica entre os regimes autoritário e democrático, v. BARROSO, Luís Roberto. Vinte anos da Constituição Brasileira de 1988: o Estado a que chegamos. In: Temas de direito constitucional, t. IV. Rio de Janeiro: Renovar, 2009, p. 50 e ss. Na mesma linha, cfr. SARMENTO, Daniel. Por um constitucionalismo inclusivo: história constitucional brasileira, teoria da Constituição e direitos fundamentais. Rio de Janeiro: Lumen Juris, 2010, p. 102 e ss. Vale destacar que a expressão ativismo judicial foi cunhada nos Estados Unidos, sendo empregada, sobretudo, "como rótulo para qualificar a atuação da Suprema Corte durante os anos em que foi presidida por Earl Warren, entre 1954 e 1969. Ao longo desse período, ocorreu uma revolução profunda e silenciosa em relação a inúmeras práticas políticas nos Estados Unidos, conduzida por uma jurisprudência progressista em matéria de direitos fundamentais. (...). A partir daí, por força de uma intensa reação conservadora, a expressão ativismo judicial assumiu, nos Estados Unidos, uma conotação negativa, depreciativa, equiparada ao exercício impróprio do poder judicial. Todavia, depurada essa crítica ideológica - até porque pode ser progressista ou conservadora - a ideia de ativismo judicial está associada a uma participação mais ampla e intensa do Judiciário na concretização dos valores e fins constitucionais, com maior interferência no espaço de atuação dos outros dois 
do magistrado pode gerar desequilíbrio na moldura institucional em que se assentam as democracias contemporâneas, com a separação do poder político entre as esferas administrativa, legislativa e judiciária. ${ }^{7}$ No modelo contemporâneo de equilíbrio entre poderes, ${ }^{8}$ a atuação dos agentes públicos, entre a ousadia e a prudência, mostra-se imprescindível na efetivação dos preceitos constitucionais.

Certo é que ao intérprete, independentemente de sua boa intenção em favor de certos direitos com assento no ordenamento, não é dado julgar conforme a sua consciência, ${ }^{9}$ encontrando-se vinculado à ordem jurídica, em cujo contexto caberá construir solução para os casos concretos a partir dos princípios constitucionais, o mais das vezes veiculados por meio da técnica das cláusulas gerais. ${ }^{10} \mathrm{~A}$ partir desta técnica, as Constituições e os legisladores contemporâneos, convencidos de sua própria incapacidade para regular todas as numerosas e multifacetadas situações nas quais a pessoa humana se insere e exige tutela, franqueiam espaço

Poderes. Em muitas situações, sequer há confronto, mas mera ocupação de espaços vazios" (BARROSO, Luís Roberto. O novo direito constitucional brasileiro: contribuições para a construção teórica e prática da jurisdição constitucional no Brasil. Belo Horizonte: Fórum, 2014, pp. 244-246). Sob a rubrica do chamado ativismo judicial, por exemplo, inclui-se a vedação à segregação racial nas escolas (Brown v. Board of Education, 1954).

7 Por todos, BINENBOJM, Gustavo. A Nova Jurisdição Constitucional Brasileira: legitimidade democrática e instrumentos de realização, Rio de Janeiro: Renovar, 2014, pp. 91 e ss.

8 Sobre o tema, v. BRITTO, Carlos Ayres. Separação dos Poderes na Constituição Brasileira. In: Doutrinas Essenciais de Direito Constitucional, v. 4, 2011, p. 42 e ss.

9 Assim, BARROSO, Luís Roberto. Judicialização, Ativismo Judicial e Legitimidade Democrática, p. 280.

10 Neste tocante, importa destacar a noção do que se convencionou de chamar de "protagonismo judicial", associado ao fenômeno do ativismo judicial, embora gozando de suas próprias diretrizes conceituais, com fins de se atribuir, por meio das decisões dos magistrados, o maior grau de efetividade possível à Constituição da República. Diferencia-se do ativismo na medida em que não poderia servir de justificação para sobreposição dos valores e das convicções pessoais de cada julgador às escolhas legitimamente realizadas nos espaços tradicionais da política, mas apenas representaria a necessária fundamentação constitucionalmente adequada, decorrente de diálogo com o momento histórico, de modo a legitimar a atuação do Poder Judiciário. Sobre o tema, v. VIANA, lasna Chaves; VIANA, Emílio de Medeiros, Do ativismo ao protagonismo judicial: por uma atuação transformadora na seara ambiental, in Revista de Direito e Sustentabilidade, vol. 2, n. 2, Jul/Dez.2016, pp. 74-75. Disponível em: http://indexlaw.org/index.php/revistards/article/view/1252/1684. Nas palavras de Boaventura de Sousa Santos: "Em primeiro lugar, tal protagonismo é produto de uma conjunção de fatores que evoluem historicamente, pelo que se torna necessário periodizar a função e o poder judiciais nos últimos 150 anos a fim de podermos contextualizar melhor a situação presente. Em segundo lugar, as intervenções judiciais que são responsáveis pela notoriedade judicial num dado momento histórico constituem uma fração ínfima do desempenho judiciário, pelo que um enfoque exclusivo nas grandes questões pode ocultar ou deixar sub analisado o desempenho que na prática cotidiana dos tribunais ocupa a esmagadora maioria dos recursos e do trabalho judicial. Em terceiro lugar, o desempenho dos tribunais, quer o desempenho notório, quer o desempenho de rotina, num determinado pais ou momento histórico concreto, não depende tão só de fatores políticos, como as questões da legitimidade, da capacidade e da independência podem fazer crer. Depende de modo decisivo de outros fatores e nomeadamente dos três seguintes: do nível de desenvolvimento do país e, portanto, da posição que este ocupa no sistema mundial e na economia-mundo; da cultura jurídica dominante em termos dos grandes sistemas ou famílias de direito em que os comparatistas costumam dividir o mundo; e do processo histórico por via do qual essa cultura jurídica se instalou e se desenvolveu (desenvolvimento orgânico; adoção voluntarista de modelos externos; colonização etc.)." (SANTOS, Boaventura; Marques, Maria Manuel Leitão; Pedroso, João. Os Tribunais nas Sociedades Contemporâneas. Revista Brasileira de Ciências Sociais (ANPOCS). RBCS 30, 1996, p.1-20. Disponível em: http://www.anpocs.org.br/portal/publicacoes/rbcs_00_30/rbcs30_07.htm. Acesso em: 19 de novembro de 2018). 
amplo de atuação do intérprete, o qual, contudo, não poderá se afastar do dever de promoção da axiologia constitucional.

Insere-se neste contexto a reflexão acerca do ativismo judicial na experiência brasileira. Objetiva-se promover reflexão acerca da evolução e dos pressupostos próprios do Judiciário brasileiro, em especial atenção aos perigos camuflados na adoção de técnica interpretativa conservadora, ressaltando-se o esforço metodológico das últimas décadas na construção de hermenêutica que seja, a um só tempo, comprometida com a efetividade das normas constitucionais na complexidade do ordenamento e vinculada à estrutura institucional da democracia constitucional, em que não se admitem soluções subjetivas e discricionárias por parte da magistratura, descompromissadas com os valores do sistema jurídico.

\section{REALIDADE SOCIAL E FENÔMENO JURÍDICO NA COMPLEXIDADE DO ORDENAMENTO}

A alteração do perfil do Poder Judiciário coincide com a crescente solução de controvérsias interprivadas com fundamento em princípios constitucionais nem sempre refletidos na legislação infraconstitucional, cuja aplicação mecânica, no caso concreto, levaria ao sacrifício de valores constitucionalmente relevantes. Daí a necessária reflexão sobre a denominada constitucionalização do direito civil, que se associa à mudança do papel do Código Civil nas relações jurídicas de direito privado.

O despertar do Direito Civil (e, por conseguinte, da magistratura) para a vida além do Código, na tentativa de abrir o sistema e buscar o conteúdo normativo dos preceitos codificados a partir do compromisso constitucional da sociedade, relaciona-se, por sua vez, a duas circunstâncias históricas que alteraram radicalmente a preocupação da civilística nas últimas décadas, relativizando os confins entre o direito público e o privado: (i) a dignidade da pessoa humana alçada a paradigma axiológico das relações privadas; (ii) as novas tecnologias, que alteram fundamentalmente a dogmática concernente à autonomia privada, tanto do ponto de vista subjetivo, quanto dos pontos de vista objetivo e formal. Deve-se conceber a constitucionalização do direito civil, portanto, não 
como o deslocamento topográfico de normas de direito privado para cartas políticas ou tratados internacionais, mas como procedimento metodológico de compreensão do ordenamento em sua complexidade, no âmbito do qual os valores constitucionais se incorporam aos normativos e à própria racionalidade da legislação infraconstitucional.

Cuida-se de trajetória que invoca a profunda alteração do papel das codificações atuais em relação ao Códigos dos Séculos XVIII e XIX, dentre os quais se destaca a primeira codificação brasileira, cujo pensamento cultural ainda povoa o imaginário de muitos doutrinadores na atualidade. Com efeito, o Código Civil de 1916 refletia o pensamento dominante das elites europeias do século XIX, marcadamente individualista e liberal. O indivíduo, considerado sujeito de direito por sua capacidade de ser titular de relações patrimoniais, deveria ter plena liberdade para a apropriação, de tal sorte que o direito civil se estruturava a partir de dois grandes pilares, o contrato e a propriedade, instrumentos que asseguravam o tráfego jurídico de aquisição e de preservação do patrimônio. Expressão normativa da Escola da Exegese, movimento inspirado pelo racionalismo, cujas origens romano-medievais foram retomadas e reelaboradas nos séculos XVIII e XIX, o Código Civil pretendia ser o corpo jurídico único e exclusivo das relações patrimoniais. Tal exclusividade normativa constituía elemento de segurança social. ${ }^{11}$

O Código Civil exercia esse papel de corpo normativo único das relações patrimoniais privadas e atendia plenamente à preocupação - que se tornou um verdadeiro mito - da completude, como forma de oferecer segurança à sociedade burguesa quanto às chamadas regras do jogo. O juiz tem o dever de julgar

11 Tullio Ascarelli, em página de aguda atualidade, analisa o conflito entre as codificações do Século XIX, moldadas por valores de sociedades rurais e pré-industriais, e a realidade econômica pós-industrial, especialmente após o segundo pós-guerra europeu, a exigir do intérprete a "reconstrução tipológica da realidade". É ver-se: "Ė così la stessa necessità di umana applicazione del diritto, in una realtà sempre mutevole perchè identica con la stessa storia umana, che impone la continua ricostruzione tipologica alla quale è indotto l'interprete e proprio per conciliare con la storicità e la concretezza della realtà, la costanza di un dato in realtà così sempre rinnovato nel rinnovamento di quella schematizzazione della realtà alla quale si referisce la disciplina, perciò stesso (e solo perciò) applicabile" (ASCARELLI, Tullio. Problemi giuridici, tomo primo. Milano: Casa Editrice Dott. A. Giuffrè, 1959, pp. 75-76). Em tradução livre: "É, portanto, a mesma necessidade de aplicação humana do direito, em uma realidade sempre mutável, porque idêntica com a mesma história humana, que impõe a contínua reconstrução tipológica à qual é levado o intérprete, e justamente para conciliar com a historicidade e a concretude da realidade, a constância de um dado em realidade desse modo sempre renovado na renovação daquela esquematização da realidade à qual se refere a disciplina, por isso mesmo (e somente por isso) aplicável". 
todos os casos que lhe são submetidos e, em seu julgamento, deve se basear na lei, que por sua vez trata de todas as possíveis situações em que o sujeito de direito se vê em conflitos. O esquema se completava com a atribuição de grande espaço para a autonomia da vontade, de modo que as partes contratantes pudessem completar, nos casos concretos, a tarefa do legislador, que se limitava a reprimir ilícitos. Transferem-se aos contratantes, assim, os riscos e o sucesso da livre iniciativa, destinada à acumulação de capital. O dogma representado pela completude, na ideologia do liberalismo, fazia com que, de um lado, se situasse o Código Civil como norma exclusiva, levando-se ao extremo o monopólio estatal da produção legislativa concentrado em um único monumento legislativo. Por outro lado, exasperava-se a dicotomia entre o direito público e o direito privado: o direito público, responsável pelas garantias do cidadão perante o Estado; e o direito privado, expressão da razão e da natureza das coisas, conferia liberdade absoluta de contratação e de apropriação. Tais circunstâncias explicam o chamado significado constitucional do Código Civil para as relações de direito privado, bem como a compreensão da norma constitucional como mera norma de organização política, que tem como destinatário o legislador ordinário.

Este estado de coisas, cujo itinerário não se pode aqui percorrer, vai se alterando na Europa desde o início do século XX e, no Brasil, a partir dos anos 30, com a intervenção do Estado na economia, que resultaria no fenômeno conhecido como dirigismo contratual. O Direito Civil, assim como os outros ramos do chamado direito privado, assistiu a uma profunda intervenção por parte do Estado, na tentativa de evitar que a exasperação da ideologia individualista em vez de gerar o que se imaginara no século anterior, ou seja, a riqueza das nações e das pessoas - continuasse a acirrar as desigualdades, com a formação de novos miseráveis, tornando inviável até mesmo o regime de mercado, essencial ao capitalismo. A partir dessa intervenção do Estado e da configuração do dirigismo contratual, verificam-se mudanças profundas na técnica legislativa. O legislador deixa de simplesmente estabelecer as regras do jogo, passando a determinar metas econômicas, instrumentalizadas à consecução de finalidades sociais mediante políticas públicas predefinidas. A funcionalização das situações jurídicas patrimoniais a valores não patrimoniais, atinentes à pessoa humana e 
à sua personalidade, torna-se, assim, postulado imperativo da ordem jurídica, introduzida pouco a pouco pela legislação especial e consagrada, no caso brasileiro, na esteira desse processo histórico, pela Constituição da República de 5 de outubro de 1988.

A dignidade humana, alçada a fundamento da República no art. $1^{\circ}$, III, da Constituição, assume particular relevo deste processo como vetor interpretativo-integrativo de todo o ordenamento jurídico. Nesta direção, atribui-se cada vez mais aos princípios o papel de reunificação do direito civil a partir da releitura de tradicionais institutos à luz da tábua axiológica constitucional, atribuindo-se ao magistrado a missão de delimitar categorias e conceitos jurídicos indeterminados de modo a assegurar eficácia jurídica às cláusulas gerais positivadas pelo legislador. O direito civil como espaço de liberdade patrimonial garantido ao proprietário e ao contratante expande-se na promoção da liberdade substancial e da autonomia existencial na legalidade constitucional. ${ }^{12} \mathrm{O}$ modelo teórico, racional e abstrato, desvinculado da práxis, cede lugar ao pensamento tópico-sistemático, ${ }^{13}$ atento à realidade social, com características fenomenológicas diversas da ciência jurídica anteriormente concebida em sua neutralidade conceitual.

A perspectiva binária, separando realidade social e ciência jurídica, ignora que a atuação do direito depende visceralmente dos fatos, em recíproco condicionamento, de modo que a conceituação analítica das diversas espécies de fatos (jurídicos) mostra-se indispensável para a definição da disciplina normativa correspondente. Fato social é o acontecimento que, submetido à incidência do direito, torna-se, tecnicamente, fato jurídico. Afirma-se, por isso mesmo, que um fato qualquer - pré-jurídico -, a partir do momento em que deixa de ser indiferente ao direito, adquire aptidão para gerar efeitos jurídicos. Nesta direção, se é verdade que o dado social - como elemento da realidade fática - não se confunde com o dado normativo - a norma jurídica -, parece arbitrário considerar alguns fatos simplesmente alheios ao direito, ou despidos de relevância ou pressupostos de eficácia, já que a experiência normativa alcança integralmente a vida social, mesmo os espaços de liberdade que o direito, valorando-os, preserva deliberadamente contra qualquer tipo de regulamentação.

12 Na palavra de Luiz Edson Fachin: "Da autonomia privada à liberdade substancial, das titularidades exclusivas aos deveres extraproprietários, dos modelos excludentes ao valor jurídico da afetividade, são exemplos dessa passagem da estrutura para a função, e bem assim dos princípios gerais do Direito para os princípios constitucionais como normas vinculantes" (FACHIN, Luiz Edson. Direito Civil: sentidos, transformações e fim, Rio de Janeiro: Renovar, 2015, p. 49).

Nessa perspectiva, FACHIN, Luiz Edson. Direito Civil: sentidos, transformações e fim, p. 50. 
Diante de tal circunstância, afirma-se que todo fato social interessa ao direito, já que potencialmente interfere na convivência social e, portanto, ingressa no espectro de incidência do ordenamento jurídico. Deste modo, considerando que os fatos sociais são plasmados pela ordem jurídica, que os valora em confronto com a tábua axiológica constitucional, não pode o intérprete furtar-se da análise fática que consistirá no suporte sobre o qual aplicará o ordenamento em sua unidade e complexidade. Não havendo valores pré-jurídicos, imunes a qualquer filtro valorativo, caberá ao intérprete a árdua tarefa de encontrar, a partir da técnica da ponderação, o ordenamento do caso concreto. Não se trata, aqui, de ativismo judicial, senão de pura atividade hermenêutica, essencial ao adequado funcionado do sistema.

A complexidade do ordenamento, em última análise, não decorre apenas de sua gênese - análise estrutural entre direito interno e externo e distinção cronológica e hierárquica da produção normativa -, mas da tensão dialética representada por sua inserção na realidade social. A experiência vivida forja a norma, e a cultura - como complexo de experiências econômica, religiosa, política, tecnológica - condiciona internamente o sistema jurídico e, conseguintemente, a teoria da interpretação, que assume necessariamente feição procedimental e dinâmica na formulação, pelo magistrado, da norma interpretada, ou do ordenamento do caso concreto, promulgado em cada sentença. ${ }^{14}$

\section{DIFICULDADES ENTRE A TEORIA E A PRÁTICA. OS SETE PECADOS} CAPITAIS: A PREGUIÇA

O apego à concepção cultural anteriormente criticada, que antevê a realidade jurídica em perspectiva binária (a partir da separação do fato social e do fato jurídico), associa-se à visão do direito como modelo teórico, racional e abstrato em face das turbulências da vida como ela é, com características fenomenológicas diversas da ciência jurídica, suscitando ao menos cinco graves problemas na teoria da interpretação: (i) o descompasso insolúvel entre teoria e

14 O direito, como se sabe, constitui fenômeno cultural, sendo inseparáveis as técnicas e a ideologia, a responsabilidade dos operadores do direito e a do legislador, a responsabilidade dos cidadãos e a dos políticos: "das leis chega-se à norma e ao direito com uma operação que não é mecânica, mas, sim, cultural, mediadora de interesses e de valores" (PERLINGIERI, Pietro. Perfis do direito civil. Rio de Janeiro: Renovar, 2002, p. 22). 
prática, entre o direito e a vida, aquele correndo sempre para alcançar esta, algo como o inconsolável cachorro que se desespera em torno da própria cauda; (ii) o fortalecimento da lex mercatoria, que capta melhor essa realidade e acaba por impor a hegemonia econômica na vida social; (iii) a crise da legalidade e da democracia representativa diante da aparente insensibilidade do dado legislativo, que, por definição, não dá conta - e nunca dará conta - de compor os conflitos da realidade social; (iv) a mistificação do precedente jurisdicional, que significaria a feliz solução para problema anterior, a simplificar a vida da Justiça, demonizando-se os enunciados normativos por sua distância da vida real; ( $v$ ) a dificuldade de aplicação da norma constitucional como o mais distante desses modelos normativos, já que desprovida da lógica racional-descritiva típica das regras jurídicas.

Tais problemas sintetizam, em alguma medida, as dificuldades interpostas entre a teoria (civilística) e a práxis (jurisprudencial), as quais se traduzem, de forma alegórica, naquilo que se poderia bem designar - tomando-se por empréstimo a teologia católica imortalizada nos versos de Dante Alighieri - os sete pecados capitais do intérprete (tanto na academia quanto na magistratura). Em primeiro lugar, incorrendo no pecado da preguiça, tem-se o reiterado recurso ao silogismo na aplicação do direito, mediante a técnica da subsunção. ${ }^{15}$

Como se sabe, o magistrado tem o dever de julgar as controvérsias que lhe são submetidas, desde que no âmbito de sua competência e se encontrando presentes os pressupostos e as condições da ação. E deve fazê-lo com base no ordenamento: ${ }^{16}$ unitário, complexo e sistemático. ${ }^{17}$ Vale-se de princípios e valores

15 "Aquele que a existência assim consuma, / Tal vestígio de si deixa na terra, / Como o fumo no ar e na água a espuma. / Ergue-te, pois! Torpor de ti desterra! / Recobra o esforço que os perigos vence! / Impere alma no corpo em que se encerra!" (Inferno, Canto XXIV, versos 49-54). "Pressa; pressa! De tempo já sem perda! / Pouco zelo não haja! - outros clamaram - / Não refloresce a Graça n’alma lerda! (Purgatório, Canto XVIII, versos 103-105).

16 Norberto Bobbio associa o problema da completude do ordenamento jurídico à dinâmica dos sistemas em que vigorem duas regras: "1) o juiz é obrigado a julgar todas as controvérsias que se apresentarem ao seu exame; 2) deve julgá-las com base em uma norma pertencente ao sistema. Entende-se que, se uma das duas regras perder o efeito, a completude deixará de ser considerada como um requisito do ordenamento. Podemos imaginar dois tipos de ordenamentos incompletos, caso falte a primeira ou a segunda regra. Num ordenamento em que faltasse a primeira regra, o juiz não teria que julgar todas as controvérsias que lhe fossem apresentadas: poderia pura e simplesmente repelir o caso como juridicamente irrelevante, com um juízo de non liquet (não convém). (...) Num ordenamento no qual faltasse a segunda regra, o juiz seria, sim, levado a julgar cada caso, mas não seria obrigado a julgá-lo baseado em uma norma do sistema" (BOBBIO, Noberto. Teoria do ordenamento jurídico. Brasília, UnB, 1995, pp. 118-119).

17 Pietro Perlingieri observa a influência recíproca entre direito e realidade social e daí faz derivar os seguintes corolários, caracterizadores do ordenamento jurídico: "a) historicidade da societas e historicidade do ius são um todo único; b) o ius coincide com a societas sem exaurir-se na pura normatividade; c) o ius, que justamente pode 
que uniformizem o sentido das decisões, reconduzindo-as da fragmentação da casuística à unidade axiológica indispensável à compreensão do ordenamento como sistema. Para tanto, não pode levar em conta uma regra isoladamente considerada, ainda que apropriada para a hipótese, mas o conjunto das normas inserido no ordenamento. ${ }^{18}$ Nada obstante, a persistência da subsunção devese à aparente neutralidade técnica de sua utilização, mediante operação lógica conhecida como silogismo, pela qual o processo interpretativo consistiria na identificação da previsão legislativa geral e abstrata (chamada premissa maior) contendo a hipótese fática em questão (chamada de premissa menor). A etapa seguinte seria mecânica, mediante a aplicação da premissa maior à premissa menor, enquadrando esta àquela. ${ }^{19}$

Entretanto, a despeito da racionalidade lógica do silogismo, há duas premissas equivocadas que autorizam a subsunção. A primeira delas é a separação entre o mundo abstrato das normas e o mundo real dos fatos no qual aquelas devem incidir, já que, a rigor, o direito se insere na sociedade e, por conseguinte, os textos legais e a realidade mutante se condicionam mutuamente no processo interpretativo. Em segundo lugar, a subsunção distingue artificialmente o momento da interpretação da norma abstrata (identificação da premissa maior) e o momento da aplicação da norma ao suporte fático concreto (enquadramento da premissa menor ao texto normativo). Contrariamente a tal compreensão, não é possível interpretar a norma aplicável sem levar em conta a hipótese fática que, por sua vez, se encontra moldada pelas normas de comportamento estabelecidas pelo direito (o qual condiciona a atuação individual). Daí a unicidade da interpretação e da aplicação, sendo falsa a ideia de que haveria normas ideais em abstrato, capazes de tipificar e captar as relações jurídicas em concreto. ${ }^{20}$

se definir totalidade da experiência jurídica, é, como qualquer totalidade, necessariamente complexidade; d) a complexidade do ius exige que a sua análise não perca a sua necessária unidade; e) tal unidade conceitual é síntese individual somente na efetividade da sua aplicação" (PERLINGIERI, Pietro. O direito civil na legalidade constitucional, trad. Maria Cristina de Cicco. Rio de Janeiro: Renovar, 2008, p. 194).

18 Ao propósito, afirmou-se que "não se interpreta o direito em tiras; não se interpreta textos normativos isoladamente, mas sim o direito no seu todo, marcado, na dicção de Ascarelli, pelas suas premissas implícitas" (GRAU, Eros. Ensaio e discurso sobre a interpretação/aplicação do direito. 5. ed. São Paulo, Malheiros, 2009, p. 101).

19 Para a descrição da subsunção em sua perspectiva clássica, v., por todos, ENGISCH, Karl. Introdução ao pensamento jurídico. 8. ed. Lisboa: Calouste Gulbekian, 2001, p. 94.

20 Para uma crítica veemente à subsunção em julgamento do Supremo Tribunal Federal, v. STF, ADIn 3.689/PA, Tribunal Pleno, Rel. Min. Eros Grau, julg. 10.5.2007. 
Mediante o raciocínio da subsunção, reduz-se a atividade do magistrado à aplicação mecânica da norma ao fato concreto, procedimento que se torna ainda menos criativo quando o texto legal é considerado claro: in claris non fit interpretatio, eis o brocardo que se tornou verdadeiro dogma para a hermenêutica clássica. Ainda como consequência de tal orientação, a norma infraconstitucional, porque tendencialmente mais detalhada, torna-se protagonista do processo de interpretação do direito, exercendo papel de mediadora entre os princípios e o suporte fático sobre o qual incide. Já os princípios constitucionais, incompletos como modelo abstrato de comportamento, mostram-se inaptos para exercerem a função de premissa maior da subsunção, o que os torna coadjuvantes das regras, a despeito de sua superioridade hierárquica sobre estas. Desse modo, a tarefa do intérprete circunscreve-se à adequação do conteúdo principiológico à regra infraconstitucional, a qual será legítima desde que não viole frontalmente o texto constitucional. Reduz-se, assim, a força normativa da Constituição ao conteúdo estabelecido pelo legislador infraconstitucional. O princípio, em uma palavra, será aquilo que o legislador infraconstitucional entender sê-lo. $E$ como, por exigência prática, quanto mais pedestre se situar a regra na pirâmide normativa mais analítica e minuciosa será a sua linguagem, os valores e princípios constitucionais transformam-se em limite remoto à atuação (teratológica) do legislador ordinário.

Em direção oposta, consolida-se hoje o entendimento de que cada regra deve ser interpretada e aplicada em conjunto com a totalidade do ordenamento, refletindo a integralidade das normas em vigor. A norma do caso concreto é definida pelas circunstâncias fáticas nas quais incide, sendo extraída do complexo de textos normativos em que se constitui o ordenamento. O objeto da interpretação são as disposições infraconstitucionais integradas visceralmente às normas constitucionais, sendo certo que cada decisão abrange a totalidade do ordenamento, complexo e unitário. Cada decisão judicial, nessa perspectiva, é um ordenamento singular extraído da mesma tábua axiológica. ${ }^{21}$ Curiosamente, o último bastião em defesa da subsunção tem sido a possibilidade de

21 Assim, PERLINGIERI, Pietro. Complessità e unitarietà dell'ordinamento giuridico vigente. Rassegna di diritto civile, vol. 1, 2005. Edizioni Scientifiche Italiane, p. 192. No mesmo sentido, TEPEDINO, Gustavo. Normas constitucionais e direito civil na construção unitária do ordenamento. In: Temas de direito civil, t. 3 . Rio de Janeiro: Renovar, 2009, p. 11. 
excepcioná-la como válvula de escape para o sistema. Admite-se, deste modo, em hipóteses específicas, que o magistrado possa valer-se de princípios, afastando a previsão regulamentar, nos chamados casos difíceis - hard cases -, assim discricionariamente compreendidos certos casos sensíveis à sociedade, dignos de comoção popular, que justificariam, ao contrário de todas as outras causas julgadas pelo mesmo magistrado - e consideradas (a contrario sensu) fáceis -, o abandono da subsunção e a adoção franca dos princípios constitucionais. ${ }^{22}$

A solução mostra-se arbitrária e injustificada. Os chamados casos difíceis são aqueles que, por sua suposta dificuldade, decorrente de colisão de direitos, autorizariam o juiz a afastar regra expressa, que lhe serviria comodamente de premissa maior, evitando a subsunção em favor da ponderação. Todavia, cada caso concreto mostra-se sempre singular e difícil, devendo ser resolvido mediante a aplicação integral do ordenamento - insista-se: unitário, complexo, sistemático e coerente. ${ }^{23}$ Mesmo quando aparentemente o magistrado aplica somente uma regra, de linguagem clara e direta, vale-se, a rigor, de cada uma das normas que convivem unitariamente no ordenamento, reclamando coerência e inter-relação normativa; e especialmente dos princípios que lhe dão fundamento, respeitada a hierarquia constitucional. Por isso, e a despeito da dificuldade em estabelecer a fronteira entre casos difíceis e fáceis, não se pode considerar a ponderação como expediente excepcional, a ser utilizado em hipóteses extremas, quando não fosse possível a aplicação mecânica das regras, sob pena de se subverter a hierarquia do ordenamento.

Tais conclusões estimulam a revisão do conceito de segurança jurídica. A subsunção propicia a falsa impressão de garantia de igualdade na aplicação da lei. Entretanto, não há respeito à isonomia quando o magistrado deixa de perceber a singularidade de cada caso concreto e, mediante procedimento mecânico, faz prevalecer o texto abstrato da regra. Por outro lado, o silogismo revela-se capaz de camuflar intenções subjetivas ou ideológicas do magistrado, poupando-lhe da imperiosa necessidade de justificar sua decisão e oferecendo-lhe

22 Nessa direção, v. BARCELLOS, Ana Paula de. Ponderação, racionalidade e atividade jurisdicional, Rio de Janeiro: Renovar, 2005, p. 296; BARROSO, Luís Roberto. O novo direito constitucional brasileiro: contribuições para a construção teórica e prática da jurisdição constitucional no Brasil, p. 154; ÁVILA, Humberto. Teoria dos princípios: da definição à aplicação dos princípios jurídicos. São Paulo: Malheiros, 2016, p. 97.

BOBBIO, Norberto. Teoria do ordenamento jurídico, pp. 34-35. 
salvo-conduto para escapar do controle social quanto à aderência de sua atividade interpretativa à axiologia constitucional. Segurança jurídica deve ser alcançada pela compatibilidade das decisões judiciais com os princípios e os valores constitucionais, que traduzem a identidade cultural da sociedade. Em alguma medida, as novas tecnologias denunciam, com o dinamismo de sua evolução, o ocaso da ideologia da subsunção. Surgem a cada dia questões inovadoras, sequer cogitadas pelo legislador, muito distantes das previsões abstratas pretensamente capazes de regular o comportamento social. Basta pensar no impacto das tecnologias de captação, armazenamento e divulgação de imagens na tutela da personalidade; das tecnologias de comunicação na formação dos contratos; das tecnologias de construção e exploração econômica sobre a propriedade e outros direitos reais; das tecnologias reprodutivas sobre o direito de família e de sucessões, e assim por diante.

Reflexo ainda dessa ideologia da subsunção e da diminuta relevância por ela reservada às peculiaridades do caso concreto mostra-se o entendimento jurisprudencial, consolidado nos Tribunais Superiores, pelo qual o simples reexame de provas não justifica os Recursos Especial e Extraordinário. Nesta direção unificaram-se a jurisprudência das Súmulas 279, do STF ("Para simples reexame de prova não cabe recurso extraordinário") e 7, do STJ ("A pretensão de simples reexame de prova não enseja recurso especial"). Do mesmo modo, tem se afirmado, no âmbito dos tribunais estaduais, corroborando o vetusto brocado segundo o qual in claris non fit interpretatio, a "possibilidade de julgamento monocrático pelo relator em virtude da existência de texto expresso de lei que não enseja dúvida de interpretação". ${ }^{24}$

Tal entendimento jurisprudencial, forjado pela compreensível preocupação de reduzir o número de processos nos Tribunais Superiores, certamente causa embaraço aos eminentes julgadores, os quais dificilmente poderiam explicar sua

24 Ilustrativamente, vejam-se os seguintes julgados do Tribunal de Justiça do Estado do Rio de Janeiro: TJRJ, 18a C.C., Ap. Cív. 0021293-74.2012.8.19.0204, julg. 5.4.2016; TJRJ, 10ª C.C., Ap. Cív. 0008238-54.2006.8.19.0014, julg. 10.10.2016. O entendimento resulta de enunciado aprovado no âmbito das "Primeiras Reflexões de Desembargadores do TJRJ sobre o CPC de 2015", afirmando-se que "as hipóteses previstas nos artigos 932, incisos IV e V, e 955, parágrafo único, ambos do CPC de 2015, são exemplificativas, podendo o relator decidir monocraticamente, v.g., com base em pronunciamento judicial dotado de eficácia vinculante (artigo 927, incisos I e V, do CPC de 2015), em julgamento emanado da Corte Especial do STJ e quando houver texto expresso de lei, que não suscite dúvida de interpretação" (grifou-se). 
atuação jurisdicional sem a indispensável análise dos fatos concretos e de suas circunstâncias traduzidas no material probatório. Ao propósito, há quem sustente a inconstitucionalidade de tal posicionamento, observando que "a aplicação do direito expresso na Súmula acabou por fazer com que em muitas situações o STJ se visse tolhido no seu propósito de ministrar a Justiça". ${ }^{25}$ Diante do rigor das aludidas Súmulas, alguns julgadores procuram, com razão, contornar a dicção dos enunciados, construindo valorosa tese segundo a qual o reexame das provas não se confunde com a sua revaloração: "a revaloração da prova constitui em atribuir o devido valor jurídico a fato incontroverso sobejamente reconhecido nas instâncias ordinárias". ${ }^{26}$ Na perspectiva que se procurou traçar, não há interpretação jurídica sem qualificação do fato, cujo exame, portanto, se faz imprescindível e insuperável. A valoração da prova pelo magistrado, em outras palavras, ocorrerá necessariamente na medida em que procure compreender os fatos para analisar a incidência normativa (norma do fato concreto qualificado pelo intérprete à luz da integralidade do ordenamento).

A valoração dos direitos a partir do seu exercício, que somente in concreto se poderá aferir, remete à já mencionada crítica à dicotomia entre a realidade social e os modelos jurídicos e, em consequência, à necessária superação da distinção entre fato social e fato jurídico. O desafio do intérprete, portanto, consiste em atingir o equilíbrio em atividade hermenêutica que, fugindo à facilidade tentadora dos silogismos, considere o ordenamento em sua unidade e complexidade sem, contudo, derivar para ativismo irresponsável, de criação livre do direito, despreocupado com o desenho institucional democrático que deve pautar a atuação do Estado, inclusive o Estado-juiz.

Como instrumento imprescindível ao intérprete neste desafio que se the apresenta, tem-se a ponderação como técnica de sopesamento dos diversos vetores normativos incidentes no caso concreto. Por isso mesmo, a ponderação não deve ser adotada apenas na aplicação de princípios, mas também entre regras, e regras e princípios, já que todos os enunciados normativos dialogam entre si, contemporaneamente, sob a mesma tábua axiológica. ${ }^{27} \mathrm{E}$ a valoração prévia 25 MOREIRA, Joaquim Manhães. Revaloração das provas pelos tribunais. Valor Econômico. São Paulo, 17.4.2012. Disponível em: http://ibetbrasil.com.br/noticias/index.php?option=comcontent\& view=article\&id=8117:revaloracaoda-provas-pelos-tribunais\&catid=1:noticias\&ltemid=3. Acesso em: 10.5.2017.

26 STJ, $4^{\mathrm{a}}$ T., AgRg no REsp. 1.036.178/SP, julg. 13.12.2011.

27 A doutrina constitucionalista costuma restringir a técnica da ponderação às hipóteses de compatibilização de 
do legislador, na sociedade democrática, não afasta, antes reclama, o exercício do dever inderrogável do magistrado de compatibilizar as escolhas legislativas com as escolhas efetuadas pelo constituinte. ${ }^{28} \mathrm{~A}$ técnica da ponderação como mecanismo de utilização indispensável na atividade interpretativa decorre da constatação de que o texto legislativo se mostra necessariamente incompleto e de que a decisão judicial revela procedimento de construção da norma do caso concreto. Interpretação e aplicação da norma constituem-se em processo unitário, inexistindo duplicidade de etapas entre a qualificação do fato e do direito aplicável. Tal conclusão implica a definitiva superação da subsunção como método interpretativo. ${ }^{29}$ Afirmou-se, nesta direção, que o "CC não é um conjunto de normas. É um conjunto de possibilidades de normas. Um ordenamento em potência. Só será norma depois da interpretação. O intérprete desvencilha o texto do seu invólucro. A norma é o resultado da interpretação". ${ }^{30}$

princípios em conflito. Robert Alexy, referência obrigatória na matéria, descreve a técnica da seguinte maneira: "The first stage involves establishing the degree of non-satisfaction of, or detriment to, a first principle. This is followed by a second stage in which the importance of satisfying the competing principle is established. Finally, in the third stage, it is established whether the importance of satisfying the latter principle justifies the detriment to or non-satisfaction of the former" (ALEXY, Robert. Balancing, constitutional review, and representation. International Journal of Constitutional Law, vol. 3, n. 4, 2005, p. 574). Em tradução livre: "O primeiro estágio envolve o estabelecimento de graus de não-satisfação ou de prejuízo de um primeiro princípio. A este segue-se um segundo estágio no qual a importância de satisfação do princípio concorrente é estabelecida. Finalmente, no terceiro estágio, estabelecese se a importância de satisfação do último princípio justifica o prejuízo ou não satisfação do primeiro princípio". Na civilística contemporânea, mostra-se bem mais ampla a utilização da ponderação, uma vez que a noção de legalidade constitucional impõe ao intérprete "argumentar sobre normas-princípios, cuja aplicação "não assume a forma silogística da subsunção, mas aquela da otimização ao realizar o preceito" (PERLINGIERI, Pietro. O direito civil na legalidade constitucional, p. 596). No direito civil brasileiro, v., dentre outros, SCHREIBER, Anderson. Novos paradigmas da responsabilidade civil, Rio de Janeiro: Renovar, 2007, pp. 146 e ss.; NEVARES, Ana Luiza Maia. A função promocional do testamento: tendências do direito sucessório, Rio de Janeiro: Renovar, 2009, pp. 170 e ss. (em matéria de controle da autonomia privada testamentária); MAIA, Roberta Mauro Medina. Teoria geral dos direitos reais, São Paulo: Revista dos Tribunais, 2013, p. 256 e ss. (em matéria de relatividade dos efeitos obrigacionais); OLIVA, Milena Donato. Patrimônio separado: herança, massa falida, securitização de créditos imobiliários, incorporação imobiliária, fundos de investimento imobiliário, trust. Rio de Janeiro: Renovar, 2009; BANDEIRA, Paula Greco. Contrato Incompleto. São Paulo: Atlas, 2015.

28 TEPEDINO, Gustavo. A Constitucionalização do Novo Código Civil. Revista Trimestral de Direito Civil, vol. 15, Rio de Janeiro, jul-set/2003.

29 Cfr., na perspectiva do direito italiano, PERLINGIERI, Pietro. O direito civil na legalidade constitucional, p. 579.

30 GRAU, Eros. A construção do direito: da elaboração do texto à produção da norma. Palestra proferida na Faculdade de Direito da Universidade do Estado do Rio de Janeiro - UERJ, em 31.3.2008, na qual se observou, ainda: "Não há distinção entre interpretação e aplicação do direito: a interpretação do direito consiste em encontrar uma solução que só se opera na medida em que se realize a sua aplicação". No mesmo sentido, observa Lenio Streck: "Pensar que uma regra pode ser interpretada independente dos princípios ou que uma regra pode 'valer' mais do que um princípio é uma concessão ao positivismo ou uma espécie de retorno ao positivismo, como se regra e princípio contivessem uma ambiguidade, e que pudessem ser, ao mesmo tempo, um 'critério' de conhecimento (regra) e um 'critério' de explicação (princípio), aferíveis a partir do esquema representacional sujeito-objeto" (STRECK, Lenio. O papel da constituição dirigente na batalha contra decisionismos e arbitrariedades interpretativas. In: COUTINHO, Jacinto Nelson de Miranda Coutinho; MORAIS, Jose Luis Bolzan de; STRECK, Lenio Luiz. (Org.). Estudos Constitucionais. Rio de Janeiro: Renovar, 2007, p. 186). 
Exemplo emblemático das dificuldades acarretadas pela subsunção temse na decisão extraída da jurisprudência alemã em que uma transexual de identidade feminina, com órgãos genitais masculinos, pretendeu, para consolidar sua relação homoafetiva com uma mulher, celebrar a união legal prevista pela lei alemã para pessoas do mesmo sexo. A autoridade local negou-se a conceder tal permissão, ao argumento de que, sendo o seu sexo genético masculino, ser-lheia facultado o casamento com a sua parceira (previsto pelo Código Civil alemão para pessoas de sexos diferentes), não já a união legal para pessoas do mesmo sexo. Inconformada, a interessada recorreu ao juiz de primeiro grau e ao Tribunal de Apelação, sendo-Ihe, contudo, indeferido o pedido nas duas instâncias. De fato, com base em técnica subsuntiva, as previsões legais de casamento e de união de pessoas do mesmo sexo associam-se a premissas fáticas diversas, indiscutíveis e imponderáveis. A Corte Constitucional alemã, contudo, reverteu a decisão, autorizando a união homoafetiva pretendida, mediante a técnica da ponderação. ${ }^{31}$

\section{OS DEMAIS PECADOS CAPITAIS: O ORGULHO; A GANÂNCIA; A INVEJA; A AVAREZA; A GULA; A LUXÚRIA.}

O segundo pecado capital na interpretação jurídica parece ser o apego às abstrações conceituais dos grandes tratados, que consagram classificações quase imutáveis às quais devem os fatos se amalgamarem, numa espécie de renascimento do leito de Procusto, em que todos os fatos sociais devem se compatibilizar. Identifica-se aqui o pecado do orgulho.32 Orgulho de uma realidade abstrata, teórica, de elevada magnitude, cuidadosamente preservada ao longo dos séculos como verdadeira opera di formica, em que se acantona como excepcional tudo aquilo que destoa dos conceitos e das noções gerais. ${ }^{33}$ Esse verdadeiro orgulho na conservação de categorias gerais destoa da fugacidade dos fatos e dos enunciados normativos, com a ruptura das grandes classificações e institutos, como o negócio jurídico, a propriedade, a família e assim por diante (alude-se, na

$31 \quad$ Tribunal Constitucional Federal da Alemanha, BVerfGE 128, 109 (2011).

32 "Por que do orgulho assim passais a meta,/Se sois insetos no embrião somente/Vermes de formação inda incompleta?/A modo de pilar ver-se é frequente/Joelhos, peito unido, uma figura/Cornija ou teto a sustentar ingente" (Purgatório, Canto X, versos 127-132).

33 RODOTÀ, Stefano. Ideologia e tecniche della riforma del diritto civile. Rivista di diritto commerciale, I, 1967, p. 83. 
terminologia alemã, à fragmentação dos conceitos jurídicos: Umbruchcharakter). A consequência de tal perspectiva é a qualificação errônea de novas pretensões e interesses jurídicos.

Ilustrativamente, na jurisprudência brasileira, pode-se mencionar o caso Glória Trevi, amplamente difundido pela mídia. A famosa cantora mexicana foi presa, em 2000, e mantida sob custódia na carceragem da Polícia Federal em Brasília, aguardando o trâmite do processo de extradição. Neste ínterim, Glória Trevi, grávida, alegou que a gestação seria fruto de estupro do qual teria sido vítima nas dependências da Polícia Federal. Diante disso, instaurou-se no Supremo Tribunal Federal celeuma quanto à possibilidade de realização de exame de DNA utilizando-se a placenta da cantora - coletada após o parto -, com o escopo de identificar a origem genética do recém-nascido. A extraditanda, negando-se a fornecer material genético para o exame, ajuizou Reclamação no STF, ${ }^{34}$ sob o argumento de que a coleta à sua revelia representaria flagrante violação a seus direitos fundamentais. Dentre os argumentos erigidos pela Corte Suprema para deferir a realização do exame, estava o de que não haveria, no caso, colisão de direitos fundamentais, tendo em vista que a placenta seria "lixo biológico" que, após o parto, "não é mais parte do corpo da mãe". Nesta linha afirmouse: "Tampouco se diga que a realização do exame fere direito fundamental da extraditanda. Não há qualquer procedimento invasivo na coleta da placenta - que a perícia já qualificou como refugo hospitalar". Considerou-se como determinante o fato de que o material orgânico já se encontrava "separado da pessoa da paciente", de modo que não mais Ihe pertencia, sendo, portanto, uma espécie de res derelicta, despido das características próprias do bem jurídico na vetusta concepção romana. ${ }^{35}$

Pode-se destacar, ainda, como exemplo paradigmático desta tendência, a evolução jurisprudencial brasileira em matéria de família. ${ }^{36}$ Durante algumas

34 STF, Tribunal Pleno, Rcl 2040 QO/DF, julg. 21.2.2002.

35 A dissonância entre a classificação estática e a funcional dos bens jurídicos é analisada por TEPEDINO, Gustavo. Livro (eletrônico) e o perfil funcional dos bens jurídicos na experiência brasileira. In: VICENTE, Dário Moreira; VIEIRA, José Alberto Coelho; CASIMIRO, Sofia de Vasconcelos; SILVA, Ana Maria Pereira da Silva. (Org.). Estudos de Direito Intelectual em homenagem ao Prof. Doutor José de Oliveira Ascensão. Coimbra: Almedina, 2015, p. 269-287.

36 Sobre tal processo evolutivo, v. TEPEDINO, Gustavo. A disciplina civil-constitucional das relações familiares. In: Temas de Direito Civil, t. I. Rio de Janeiro: Renovar, 2008, pp. 419-443. 
décadas no século passado, qualificou-se a família extramatrimonial como união ilícita, reconhecendo-se, no entanto, incialmente, por questões humanitárias, a relação de emprego estabelecida entre o marido e a mulher dedicada aos serviços domésticos, à qual se assegurava o salário mínimo durante o tempo em que perdurara a convivência abjeta. Posteriormente, durante quase cinquenta anos, recusava-se ainda a designação de família à união constituída fora do casamento, admitindo-se, todavia, a relação societária de fato, no âmbito do direito das obrigações, estabelecida entre os companheiros na construção do patrimônio comum, como forma de se evitar o enriquecimento sem causa. Mesmo após a Constituição de 1988, que reconheceu expressamente como entidade familiar a união estável, continuou-se a negar a esta igualdade de tratamento em relação às famílias constituídas pelo casamento, o que só seria admitido, não sem espessa controvérsia (especialmente em matéria sucessória), com a vigência do Código Civil de 2002.

O terceiro pecado capital é a ganância do julgador, que pretende resolver todos os problemas segundo sua própria ideologia. A ganância se associa ao excesso de subjetivismo na fixação de standards pelo juiz, que, mesmo quando movido pela melhor das intenções, deixa de fundamentar adequadamente suas decisões com base na opção constitucional e legislativa. ${ }^{37}$ Nessa direção, encontrase o comportamento que tem sido designado de "ativismo maximalista", em que o magistrado extrapola sua atividade hermenêutica, abandona os parâmetros

37 Ainda que se reconheça que o intérprete apenas busca premissas de fundamentação para decisões que, a rigor, são tomadas a partir de visões pessoais ou mesmo preconceitos, isto não significa descartar a importância e a necessidade da fundamentação, pois "a questão metodológica se transforma em questão hermenêutica, que pode ser encarada a partir de uma perspectiva lógico-fenomenológica e não empírico-psicológica. Neste modelo, a positividade do direito encontra-se na sua cognoscibilidade pelo intérprete, na sua interpretabilidade, uma vez que o liame entre o texto e o intérprete requer a presença de ambos: nem se pode pretender que o conteúdo do texto se produza exclusivamente pelo legislador, nem que o intérprete o ignore. A hermenêutica revela a conexão fundamental entre realidade e interpretação, impondo ao intérprete constrições como adequação, razoabilidade, proporcionalidade, coerência e congruência" (KONDER, Carlos Nelson. Distinções hermenêuticas da constitucionalização do direito civil: o intérprete na doutrina de Pietro Perlingieri. In: Revista da Faculdade de Direito - UFPR, Curitiba, vol. 60, n. 1, jan./abr. 2015, pp. 207-208). Fausto Santos de Morais, em estudo acerca do princípio da proporcionalidade no imaginário jurídico brasileiro e o problema de a legitimidade do julgador "criar" princípios jurídicos, sublinha que "uma proposta de argumentação jurídica com responsabilidade - e nesse sentido caminha com a Crítica Hermenêutica do Direito -, seria fazer com que o intérprete se preocupasse (Sorge) com a explicitação dos pressupostos do seu compreender. Esse compreender, como modo-de-ser-do-direito, implica a (re)construção fenomenológica da tradição jurídica diante do caso concreto, de maneira íntegra e coerente, procurando, através da argumentação, explicitar o fenômeno compreendido. A responsabilidade hermenêutica está em assumir a condição histórica e finita do compreender, deixando aberto o espaço para que, diante da compreensão de outro fenômeno, seja possível decidir de maneira diferente, trazendo à fala, assim, aspectos da estrutura hermenêutica até então encobertos". (MORAIS, Fausto Santos de. Ponderação e Arbitrariedade: A inadequada recepção de Alexy pelo STF, Salvador: Juspodivm, 2018, p.254). 
normativos vigentes e se dedica à atividade doutrinária por vezes hermética, baseada em seus próprios critérios ou categorias, confundindo ou dificultando o controle das decisões pela sociedade. Daqui a exigência constitucional de fundamentação das decisões, ${ }^{38}$ como mecanismo legítimo (não de autocontenção ou abdicação da elevada missão da magistratura, ${ }^{39}$ mas) de transparência e controle da atividade hermenêutica do juiz pelo corpo social. ${ }^{40}$

No âmbito da responsabilidade civil, mostram-se ilustrativas dessa indesejada ganância as decisões que utilizam a cláusula geral do parágrafo único do art. 927 do Código Civil para sustentar a responsabilidade objetiva de forma ilimitada, quase a suprimir a responsabilidade subjetiva de que trata o caput do mesmo dispositivo. ${ }^{41}$ Nessa vertente, com fundamento no art. 927, parágrafo único, condenou-se o proprietário do veículo (juntamente com o condomínio) à reparação de danos causados a terceiros pelo porteiro do prédio, aduzindose: "O proprietário do veículo responde objetiva e solidariamente pelos atos culposos de terceiro que o conduz e que provoca o acidente, pouco importando que o motorista não seja seu empregado ou preposto, ou que o transporte seja gratuito ou oneroso, uma vez que sendo o automóvel um veículo perigoso, o seu mau uso cria a responsabilidade pelos danos causados a terceiros". ${ }^{42}$

Assim também se situa a hipótese em que um menino obteve indenização por danos morais e estéticos, incluindo pensão vitalícia de $75 \%$ do salário mínimo vigente, por acidente causado no manuseio de aparelho ortodôntico extra bucal sem trava de segurança. Ao tentar retirar sozinho o aparelho, o menino, sob a guarda de seus pais, feriu-se gravemente, acarretando a perda da visão de um

38 Assim dispõe o art. 93, inciso IX, da Constituição da República: "todos os julgamentos dos órgãos do Poder Judiciário serão públicos, e fundamentadas todas as decisões, sob pena de nulidade, podendo a lei limitar a presença, em determinados atos, às próprias partes e a seus advogados, ou somente a estes, em casos nos quais a preservação do direito à intimidade do interessado no sigilo não prejudique o interesse público à informação".

39 "O ativismo judicial procura extrair o máximo das potencialidades do texto constitucional, sem contudo invadir o campo da criação livre do Direito. A autocontenção, por sua vez, restringe o espaço de incidência da Constituição em favor das instâncias tipicamente políticas" (BARROSO, Luís Roberto. Judicialização, Ativismo Judicial e Legitimidade Democrática, p. 280).

40 Como anota Daniel Sarmento, "a fundamentação das decisões judiciais, muito mais do que um requisito formal da sua validade, consiste em um pressuposto da sua legitimidade no âmbito do Estado Democrático de Direito" (SARMENTO, Daniel. Ubiquidade Constitucional: Os Dois Lados da Moeda. In: NETO, Cláudio Pereira de Souza; SARMENTO, Daniel. (Coord.). A Constitucionalização do Direito: Fundamentos Teóricos e Aplicações Específicas. Rio de Janeiro: Lumen Juris, 2007, p. 146).

41 Para o exame analítico do dispositivo e de sua potencialidade hermenêutica, v., TEPEDINO, Gustavo; BARBOZA, Heloisa Helena; MORAES, Maria Celina Bodin de. Código Civil interpretado conforme a Constituição da República, v. II. Rio de Janeiro: Renovar, 2012, p. 809.

TJRJ, $21^{a}$ C.C., Ap. Cív. 0132282-14.2011.8.19.0001, julg. 25.2.2015. 
dos olhos, condenando-se, com base em responsabilidade objetiva, os dentistas responsáveis pelo tratamento. ${ }^{43}$

Muito próximo de tal postura encontra-se o quarto pecado capital, que se assemelha à inveja do intérprete em relação aos poderes eleitos. ${ }^{44}$ Há aqui comprometimento da relação entre os Poderes, com deficit de democracia quando magistrados não eleitos pretendem se assenhorar de opções valorativas. Criticase, nessa direção, o que se chamou de "oba-oba constitucional", caracterizado pela invocação vaga de princípios cujo conteúdo é livremente forjado pelo intérprete, que se recusa a admitir sua vinculação ao direito positivo e se mostra refratário a qualquer deferência ao legislador. ${ }^{45}$

A tendência por vezes se traduz no que se poderia chamar de "ativismo louvável", quando se altera o sentido do texto legal para garantir a tutela da pessoa humana à míngua de proteção estatal. Reconheceu-se, nessa direção, com o evidente propósito de tutelar os interesses existenciais de pessoa vulnerável maior interdito -, a legitimidade de adoção post mortem em família anaparental. No caso, a União postulava a anulação da adoção com o intuito principal de sustar o pagamento de benefícios previdenciários ao adotado. A Corte posicionou-se no sentido de reconhecer a validade da adoção, sem embargo da literalidade do art. 42, § 2० ${ }^{\circ}$ da Lei n. 8.069/1990 (Estatuto da Criança e do Adolescente), que dispõe: "Para adoção conjunta, é indispensável que os adotantes sejam casados civilmente ou mantenham união estável, comprovada a estabilidade da família". Para tanto, aduziu-se que "o fim expressamente assentado pelo texto legal colocação do adotando em família estável - foi plenamente cumprido, pois os irmãos, que viveram sob o mesmo teto, até o óbito de um deles, agiam como família que eram, tanto entre si, como para o então infante, e naquele grupo familiar o adotado se deparou com relações de afeto, construiu - nos limites de suas possibilidades - seus valores sociais, teve amparo nas horas de necessidades físicas e emocionais, em suma, encontrou naqueles que o adotaram a referência

$43 \quad$ Anotícia referente ao caso pode ser consultada em: <http://www.tjgo.jus.br/index.php/home/ imprensa/noticias/119tribunal/6422-ortodontistas-sao-condenados-a-pagar-r-100-mil-a-menino-que-ficou-cego-durante-tratamento> . Acesso em: 30.12.2015.

44 "Pune este círculo a culpa traiçoeira -/O mestre diz - da inveja; o açoite aplica/O amor, que os rigores Ihe aligeira/[...] Fio de ferro as pálpebras prendia/A todas, como o gavião selvage/Para domar-Ihe a condição bravia" (Purgatório, Canto XIII, versos 37-39 ss; 70-72).

SARMENTO, Daniel. Ubiquidade constitucional: os dois lados da moeda, p. 144. 
necessária para crescer, desenvolver-se e inserir-se no grupo social que hoje faz parte". ${ }^{46}$

Em hipótese diversa, autorizou-se a inserção de nome materno fictício na certidão de uma criança de três 3 anos adotada unicamente por um homem. A decisão foi tomada com base na alegação do pai adotivo de que a ausência do nome de uma mãe no registro civil estaria causando problemas, uma vez que a maioria das instituições exige, para o cadastramento, o nome materno. O pai aduziu, ainda, que o objetivo era facilitar a vida do menor em termos práticos e evitar a possibilidade de bullying escolar ou no meio social. Dentre os argumentos erigidos na sentença encontra-se o art. $3^{\circ}$ do Estatuto da Criança e do Adolescente ao determinar que devem ser asseguradas às crianças e aos adolescentes "todas as oportunidades e facilidades, a fim de lhes facultar o desenvolvimento físico, mental, moral, espiritual e social, em condições de liberdade e de dignidade" ${ }^{47}$ Há, aqui, risco de usurpação de competência legislativa por parte do Judiciário, ainda que movido por inveja bem-intencionada.

O quinto pecado capital encontra-se numa certa obsessão fazendária de alguns setores da magistratura que, preocupados com o custo das decisões para o erário, incorrem em inequívoca avareza. ${ }^{48}$ Cria-se verdadeira esquizofrenia institucional entre, de um lado, a efetivação de valores existenciais proclamados pelo Poder Constituinte e, de outro, a prioridade conferida à fazenda pública por parte do Poder Judiciário. Deixa-se de acolher pretensões justas pelo medo avaro de sacrificar a Fazenda Pública. Incorre nessa avareza em desfavor de garantias constitucionais o entendimento jurisprudencial que, alterando orientação anterior, considera que o prazo prescricional para a pretensão de restituição de tributo considerado, em controle difuso, inconstitucional tem seu termo inicial no momento da homologação do pagamento, e não na data em que a declaração de inconstitucionalidade é proclamada por ato do Senado Federal que retira a norma inconstitucional do mundo jurídico, nos termos do art. 52, X, da C.R. ${ }^{49}$ Assim, pela denominada "tese dos cinco mais cinco", o termo $46 \quad$ STJ, $3^{a}$ T., REsp 1.217.415/RS, julg. 19.6.2012.

47 A decisão, da $11^{\text {a }}$ Vara de Família e Registro Civil da Capital (TJ/PE), foi noticiada em diversos veículos de imprensa, como o que pode ser acessado em: <http://brasil.estadao.com.br/ noticias/geral,filho-adotivo-teranome-ficticio-de-mae-em-registro-de-nascimento,1510259>. Acesso em: 5.1.2015.

48 "Como a avareza em nós tinha extinguida/A propensão ao bem, aos santos feitos,/Assim nos tem justiça a ação tolhida./Pés e mãos ata em vínculos estreitos:/Enquanto a Deus prouver, nós, estendidos,/Imóveis estaremos nesses leitos" (Purgatório, Canto XIX, versos 121-126). 
Novos Estudos Jurídicos

inicial do prazo prescricional, nos casos de tributos sujeitos a lançamento por homologação, é a data em que ocorrida essa, de maneira expressa ou tácita - pelo decurso do prazo quinquenal. Com a homologação, portanto, deflagrase o prazo prescricional quinquenal para postular a restituição pelo pagamento de tributo inconstitucional, o que, em termos práticos, leva o contribuinte a ter sua pretensão fulminada pelo decurso do prazo antes mesmo da declaração de inconstitucionalidade da lei.

Em direção oposta, felizmente, andou o Superior Tribunal de Justiça ao estabelecer, mais de vinte anos após a promulgação do Código de Defesa do Consumidor, que o prazo para surgimento de vícios ocultos nos produtos ou serviços, deliberadamente deixado em aberto pelo legislador, não poderia ser reduzido ao prazo de garantia, mas se projeta, em favor do consumidor, de acordo com a natureza do bem ou serviço adquirido, por toda a vida útil legitimamente esperada pelo consumidor. ${ }^{50}$ No caso, o vendedor de máquina agrícola ajuizou ação de cobrança pleiteando os custos com o reparo do produto vendido. Reconheceu-se, contudo, a responsabilidade do vendedor pelo vício que inquinava o produto adquirido pelo recorrido, tendo sido comprovado que se tratava de defeito de fabricação.

Tão grave quanto o pecado anterior mostra-se a gula, ${ }^{51}$ constituída pela apropriação, em estruturas dogmáticas antigas, de novos bens jurídicos com elas incompatíveis. Mais uma vez tem-se aqui processo mecânico de subsunção, em que se pretende aplicar regra jurídica isoladamente a hipóteses fáticas diferenciadas, oferecendo soluções para novos problemas a partir de técnicas com estes dissonantes. Ilustra bem esta tendência a hipótese em que a usucapião extraordinária urbana, prevista para o acesso ao direito fundamental da moradia, foi negada pelo Judiciário ao argumento de que a área usucapida seria inferior

tributário. Se a lei não fixar prazo para a homologação, será ele de 05 (cinco) anos a contar da ocorrência do fato gerador" (STJ, $1^{a}$ T., AgRg no REsp 285.676/ES, julg. 22.5.2001). V., ainda, STJ, $1^{\text {a }}$ S., EREsp 435.835/SC, julg. 24.3.2004, em que restou assentado: "Não há que se falar em prazo prescricional a contar da declaração de inconstitucionalidade pelo STF ou da Resolução do Senado. A pretensão foi formulada no prazo concebido pela jurisprudência desta Casa Julgadora como admissível, visto que a ação não está alcançada pela prescrição, nem o direito pela decadência. Aplica-se, assim, o prazo prescricional nos moldes em que pacificado pelo STJ, id est, a corrente dos cinco mais cinco".

50 STJ, $4^{\text {a }}$ T., REsp 984.106/SC, julg. 4.10.2012.

51 "Os que o rosto, cantando, têm banhado / De pranto, havendo entregue à gula a vida, / Sobem, na fome e sede, o santo estado. / A fome, a sede sente-se incendida / Dos pomos pelo aroma e por frescura / Das águas, sobre as ramas espargida" (Purgatório, Canto XXIII, versos 64-69). 
ao módulo mínimo local, "não constituindo o referido imóvel, portanto, objeto legalizável, nos termos da lei municipal". Em nome do respeito à lei municipal, portanto, afastou-se a efetivação de direito fundamental do autor, simplificandose assunto complexo em mera operação matemática. ${ }^{52}$

Finalmente, o sétimo pecado capital, a luxúria, consiste no apego ao paradigma das relações patrimoniais - e ao fetiche da propriedade - na análise de questões de natureza existencial. ${ }^{53}$ Verifica-se, em consequência, promiscuidade de categorias e conceitos, valorando-se a autonomia existencial com fundamento na lógica proprietária. Na experiência norte-americana, serve de exemplo a hipótese em que a Suprema Corte declarou inconstitucional a instalação de GPS no automóvel do réu, por violação à sua intimidade, invalidando, assim, por ilícita, portentosa investigação criminal que resultara na prisão de poderoso traficante de drogas. ${ }^{54}$ $\mathrm{O}$ aresto considerou desrespeitada a $4^{\mathrm{a}}$ Emenda à Constituição e o debate se circunscreveu aos confins do direito de propriedade do réu. O GPS fora instalado em local e período que extrapolaram mandado judicial para o rastreamento, este equiparado à noção de "busca". Desacompanhado de ordem judicial (uma vez expirado o mandado), a ilegitimidade do monitoramento com GPS foi arguida com fundamento na defesa da propriedade privada. Curiosamente, mesmo o voto vencido, da Justice Sotomayor, ao afastar o precedente da inegerência em propriedade alheia (trespass test), submetendo-se exclusivamente ao precedente de Katz v. U.S. (n. 389 U.S., p. 347), que associa a tutela da $4^{a}$ emenda ao critério da 'reasonable expectation of privacy', embora louvável por se rebelar contra o

52 STJ, $4^{a}$ T., REsp 402.792/SP, julg. 26.10.2004. Contra, o TJ/RJ, em sua Súmula da Jurisprudência Predominante, a de número 317, procurando pacificar os entendimentos em torno da concepção majoritária na corte estadual, nos seguintes termos: "É juridicamente possível o pedido de usucapião de imóvel com área inferior ao módulo mínimo urbano definido pelas posturas municipais" (A publicação da Súmula data de 18.08.2014, a partir do julgamento do Incidente de Uniformização de Jurisprudência n. 001314964.2005.8.19.0202, julgamento em 14.4.2014). O STJ alterou seu posicionamento, em boa hora, como se vê no REsp 1.040.296/ES, $4^{\mathrm{a}}$ T., julg. 2.6.2015, em caso envolvendo a usucapião rural do art. 191 da C.R. Seguiu, nesta linha, o posicionamento perfilhado pelo STF sobre a usucapião extraordinária urbana (STF, Pleno, RE 422.349/RS, julg. 29.4.2015). Sobre o tema, com arguta crítica à orientação anterior, v. MONTEIRO FILHO, Carlos Edison do Rêgo. Usucapião imobiliária urbana independente de metragem mínima. Revista Brasileira de Direito Civil, v. 2, out.-dez./2014, pp. 9-29. <https://www.ibdcivil. org.br/rbdc.php?ip=123\&titulo=\%20VOLUME\%202\%20|\%20Out-Dez\% 202014\&category_id=32\&arquivo=data/ revista/pdf/rbdcivil-volume-2.pdf>. Acesso em: 4.1.2016.

53 "De luxúria fez tantas demasias/Que em lei dispôs ser lícito e agradável/Para desculpa às torpes fantasias" (Inferno, Canto V, versos 55-57); "Cantaram; cada qual como antes disse/Esposas e maridos, que hão guardado/A fé, que Deus mandou sempre os unisse: / Este modo há de ser, creio, alternado,/Enquanto os rodear a chama ardente:/A chaga por tal bálsamo e cuidado / Há de ser guarnecida finalmente" (Purgatório, Canto XXV, versos 133-139).

54 United States v. Jones ( $n^{\circ}$. 10-1259, District of Columbia Circuit, january 23, 2012, disponível em: http://www. supremecourt.gov/opinions/11pdf/10-1259.pdf). Acesso em: 4.1.2015. 
trespass test naquela hipótese, não consegue se afastar da ótica proprietária no exame de direitos da personalidade. ${ }^{55}$

Em outro julgado dos Estados Unidos sobrepuseram-se, mais uma vez, a tutela da personalidade do corpo humano (e de seus fluidos) e o conceito de propriedade. A médica Sharon Irons engravidou após coletar, durante sexo oral, o sêmen do também médico Richard O. Phillips, seu namorado. A Corte de Apelação do Illinois (Chicago) aceitou a alegação da ré de que teria uma espécie de doação do material genético, acarretando "transferência absoluta e irrevogável do título de propriedade entre doador e doadora". Por esse motivo, Phillips não teve reconhecido direito algum sobre a decisão acerca da concepção e do nascimento do filho. No entender da Corte, mesmo que houvesse um suposto "depósito", as partes não teriam acordado quanto à necessidade de devolução do bem mediante solicitação. ${ }^{56}$

Também na jurisprudência trabalhista brasileira legitimou-se o acesso (e consequente controle) do empregador ao conteúdo do correio eletrônico de seu empregado com base na titularidade dominical. Segundo tal entendimento, "o que está em jogo, antes de tudo, é o exercício do direito de propriedade do empregador sobre o computador capaz de acessar a internet e sobre o próprio provedor". A prescindir da solução concreta a ser dada para as diversas hipóteses de colisão de interesses anteriormente aludidas, o título de propriedade certamente não há de ser o paradigma para a afirmação do direito merecedor de tutela. Se assim não fosse, a propriedade do aparelho telefônico seria argumento suficiente para legitimar, por exemplo, a interceptação telefônica no âmbito das relações de trabalho.

\section{CONSIDERAÇÕES FINAIS}

Como se pode confirmar a partir do panorama jurisprudencial brasileiro, a corajosa atuação da magistratura não deve ser combatida, embora se mostre

55 Veja-se o seguinte trecho citado no voto: "Privacy is not a discrete commodity, possessed absolutely or not at all. Those who disclose certain facts to a bank or phone company for a limited business purpose need not assume that this information will be released to other persons for other purposes".

56 Esta e outras hipóteses, ilustrativas do apego do intérprete ao paradigma patrimonialista, são analisadas por TEPEDINO, Gustavo. A estranha revolta dos fatos contra o intérprete. Revista trimestral de direito civil, v. 31, jul.-set./2007. 
imprescindível a definição pela doutrina de parâmetros constitucionais para a valoração e solução de controvérsias que, multiplicadas inevitavelmente pelo exercício da cidadania inerente à dinâmica da democracia e da sociedade da informação, agitam o Judiciário sem que o legislador possa dar conta de sua específica e mutante regulamentação.

Em tal contexto, o papel constitucional da magistratura assume importância crucial para a democracia, seja em favor da segurança jurídica representada pelo respeito às leis legitimamente promulgadas, seja para tutelar direitos fundamentais de minorias, mesmo quando a intervenção do Poder Judiciário assuma feição contramajoritária. A tênue linha divisória entre essa atuação alvissareira do magistrado e o voluntarismo ideológico deve ser contornada não de modo autoritário - ainda que escamoteado por argumento de autoridade -, mas mediante o estímulo à fundamentação das decisões, exigindo-se argumentação que permita o amplo e transparente controle social da magistratura e a paulatina construção de padrões de comportamento estáveis na reconstrução da segurança jurídica - aparentemente perdida pela ocaso da técnica legislativa regulamentar.

Com efeito, o desenvolvimento de técnicas hermenêuticas que auxiliem o intérprete na identificação de critérios substanciais úteis ao exercício de ponderação permite que se afaste a subsunção, impondo-se a consideração das circunstâncias concretas na formulação da norma interpretada, sempre de acordo com os valores do ordenamento, sem distinguir casos fáceis ou difíceis. Por outro lado, tais técnicas, como a razoabilidade, constantemente invocada nos tribunais brasileiros, não prescindem da construção de fundamentação argumentativa suscetível de controle. E mesmo a razoabilidade, nessa esteira, não se encontra imune à relatividade e à historicidade. Não se configura, portanto, postulado neutro e permanente. ${ }^{57}$ Nessa esteira se situa o esforço doutrinário voltado ao desenvolvimento de parâmetros funcionais de razoabilidade que levem em conta as especificidades de cada campo do direito civil. ${ }^{58}$ Trata-se, portanto, de

57 "La storia si evolve e con essa i sistemi giuridici e i valori-guida dei quali la ragionevolezza è una mera sintesi nel momento applicativo" (PERLINGIERI, Giovanni. Profili applicativi della ragionevolezza nel diritto civile. In: Collana: Cultura giuridica e rapporti civili, 14. Napoli: Edizioni Scientifiche Italiane, 2015, p. 26). Em tradução livre: "A história evolui e com ela os sistemas jurídicos e os valores-guia dos quais a razoabilidade é uma mera síntese no momento aplicativo".

58 Tem se destacado, nessa direção, a necessidade de que a doutrina "sinalize critérios, parâmetros e standards para o recurso às cláusulas gerais, conceitos indeterminados e princípios de forma coerente com o restante do ordenamento jurídico, em especial com a superioridade normativa do texto constitucional. A aplicação direta de normas de elevado grau de abstração exige um exercício de identificação de parâmetros a serem empregados na especificação concreta do seu conteúdo, de maneira que a uniformidade e a segurança serão tanto maiores quanto mais se tiver avançado no consenso em torno destes parâmetros" (SCHREIBER, Anderson; KONDER, Carlos Nelson. Uma agenda para o direito civil-constitucional. Revista Brasileira de Direito Civil - RBDCivil. 
construção paulatina e constante na atuação do magistrado, a partir da necessária fundamentação das decisões, mediante parâmetros materiais adequados ao caso concreto, como forma de ponderar os interesses relevantes em disputa e alcançar a solução que promova os valores do ordenamento, considerado em sua unidade e complexidade. ${ }^{59}$

Segue-se daí a importância de se evitar a contaminação dos novos valores e categorias que compõem a teoria da interpretação contemporânea por métodos e tendências extraídos da dogmática tradicional, que guarda constrangedora incompatibilidade com a legalidade constitucional. Tal perigo, recorrente e iminente, encontra-se representado, ainda que de forma reducionista, como os sete pecados capitais do intérprete, todos eles interligados e reproduzidos quer no ensino jurídico, quer na manualística, quer na prática judiciária. Não se mostra infrequente, por exemplo, a designação dos princípios constitucionais, situados no ápice da pirâmide normativa, como princípio geral de direito, previsto no art. $4^{\circ}$ da LINDB como instrumento residual de integração, formulado pelo intérprete pelo método indutivo, em nível infraconstitucional, na ausência de lei, analogia ou costume aplicáveis. Cuida-se de subversão hermenêutica que impede a preservação da unidade do ordenamento construída a partir (e com a incorporação plena) das normas constitucionais. Muito já se evoluiu, nas últimas décadas, na experiência brasileira, no campo da interpretação. E o só fato de se refletir, entre os diversos domínios do direito público e privado, acerca do ativismo judicial, indica provavelmente o itinerário vicejante e auspicioso, posto

vol. 10, 2016, p. 16. Disponível em: https://www.ibdcivil.org.br/image/data/revista/volume10/rbdcivil_vol_10_02_ doutrina-nacional_uma-agenda.pdf. Acesso em: 10.5.2017).

59 Nada obstante a influência da ideologia do intérprete, afigura-se possível a legitimação científica de decisões guiadas pelo esforço de persuasão e convencimento. Como observa Carlos Nelson Konder, "as escolhas do intérprete devem ser assumidas expressamente, não como forma a libertá-lo do Direito institucionalizado, mas exatamente para permitir o debate argumentativo acerca da sua adequação ao ordenamento: trata-se da responsabilidade do intérprete. Por meio da fundamentação, verificam-se os argumentos que levaram o intérprete a escolher, é nela em que se encontram os parâmetros para compreender a decisão. Pela fundamentação, verificase se os elementos extrajurídicos foram absorvidos por meio de elementos normativos, se os valores referidos são sociais e culturais e não pessoais: viabiliza-se, em última instância, um controle final sobre os argumentos adotados. Isso significa que a derrubada do limite externo, formal, que restringia o intérprete - o dogma da subsunção - não importa a consagração do arbítrio, mas sim a imposição de um limite interno, metodológico: a exigência de fundamentação das decisões judiciais. A ampliação da área de liberdade conferida aos magistrados, em comparação com a tradição da história jurídica, impõe uma atenção maior às justificativas invocadas para essas decisões. Nessa linha, ainda que os magistrados tomem decisões partindo de visões pessoais ou mesmo preconceitos e depois busquem as premissas para fundamentá-las, isso não significa descartar a importância e a necessidade da fundamentação" (KONDER, Carlos Nelson. Princípios contratuais e exigência de fundamentação das decisões: boa-fé e função social do contrato à luz do CPC/2015. Revista Opinião Jurídica. Fortaleza, ano 14, n. 19, jul./dez. 2016, p. 37). 
nada linear, em direção a ordem jurídica mais justa, igualitária e democrática.

\section{REFERÊNCIAS DAS FONTES CITADAS}

ALEXY, Robert. Balancing, constitutional review, and representation. International Journal of Constitutional Law, vol. 3, n. 4, 2005.

ASCARELLI, Tullio. Problemi giuridici, tomo primo, Milano: Casa Editrice Dott. A. Giuffrè, 1959. ÁVILA, Humberto. Teoria dos princípios: da definição à aplicação dos princípios jurídicos. São Paulo: Malheiros, 2016.

AYRES BRITTO, Carlos. "Separação dos Poderes na Constituição Brasileira", in Doutrinas Essenciais de Direito Constitucional, v. 4, mai./2011.

BANDEIRA, Paula Greco. Contrato Incompleto, São Paulo: Atlas, 2015.

BARCELLOS, Ana Paula de. Ponderação, racionalidade e atividade jurisdicional, Rio de Janeiro: Renovar, 2005.

BARROSO, Luís Roberto. O novo direito constitucional brasileiro: contribuições para a construção teórica e prática da jurisdição constitucional no Brasil, Belo Horizonte: Fórum, 2014.

"Vinte anos da Constituição brasileira de 1988: o Estado a que chegamos", in Temas de direito constitucional, t. IV, Rio de Janeiro: Renovar, 2009.

"Judicialização, Ativismo Judicial e Legitimidade Democrática", in Constituição e Ativismo Judicial: limites e possibilidades da norma constitucional e da decisão judicial, org. Jacinto Nelson de Miranda Coutinho; Roberto Fragale Filho; Ronaldo Lobão, Rio de Janeiro: Lumen Juris, 2011.

BINENBOJM, Gustavo. A Nova Jurisdição Constitucional Brasileira: legitimidade democrática e instrumentos de realização, Rio de Janeiro: Renovar, 2014.

BOBBIO, Norberto. Teoria do ordenamento jurídico, Brasília, UnB, 1995

BRITTO, Carlos Ayres. Separação dos Poderes na Constituição Brasileira. in Doutrinas Essenciais de Direito Constitucional, v. 4, 2011.

ENGISCH, Karl. Introdução ao pensamento jurídico, Lisboa: Calouste Gulbekian, 2001.

FACHIN, Luiz Edson. Direito Civil: sentidos, transformações e fim, Rio de Janeiro: Renovar, 2015.

GOMES, Juliana Cesario Alvim. Por um constitucionalismo difuso: cidadãos, movimentos sociais e o significado da Constituição, Salvador: JusPodivm, 2016.

GRAU, Eros. A construção do direito: da elaboração do texto à produção da norma. Palestra 
proferida na Faculdade de Direito da Universidade do Estado do Rio de Janeiro - UERJ, 31.3.2008.

. Ensaio e discurso sobre a interpretação/aplicação do direito, São Paulo: Malheiros, 2009.

HABERMAS, Jürgen. "Popular sovereignty as procedure", in Deliberative democracy, org. James Bonham; William Rehg, Cambridge, The MIT Press, 1997.

KONDER, Carlos Nelson. Distinções hermenêuticas da constitucionalização do direito civil: o intérprete na doutrina de Pietro Perlingieri, in Revista da Faculdade de Direito - UFPR, Curitiba, vol. 60, n. 1, jan./abr. 2015.

Princípios contratuais e exigência de fundamentação das decisões: boa-fé e função social do contrato à luz do CPC/2015, in Revista Opinião Jurídica, Fortaleza, ano 14, n. 19, jul./dez. 2016.

MAIA, Roberta Mauro Medina. Teoria geral dos direitos reais, São Paulo: Revista dos Tribunais, 2013.

MONTEIRO FILHO, Carlos Edison do Rêgo. Usucapião imobiliária urbana independente de metragem mínima, in Revista Brasileira de Direito Civil, vol. 2, out.-dez./2014. Disponível em: <https://www.ibdcivil.org.br/rbdc.php?ip=123 \&titulo=\%20VOLUME\%202\%20|\%200utDez\%202014\&category_id=32\&arquivo=data/revista/pdf/rbdcivil-volume-2.pdf $>$. Acesso em: 15.4.2016.

MORAIS, Fausto Santos de. Ponderação e Arbitrariedade: A inadequada recepção de Alexy pelo STF, Salvador: Juspodivm, 2018.

MOREIRA, Joaquim Manhães. Revaloração das provas pelos tribunais, Valor Econômico, public. 17.4.2012.

NEVARES, Ana Luiza Maia. A função promocional do testamento: tendências do direito sucessório, Rio de Janeiro: Renovar, 2009.

OLIVA, Milena Donato. Patrimônio separado: herança, massa falida, securitização de créditos imobiliários, incorporação imobiliária, fundos de investimento imobiliário, trust. Rio de Janeiro: Renovar, 2009.

PERLINGIERI, Giovanni. Profili applicativi della ragionevolezza nel diritto civile, in Collana: Cultura giuridica e rapporti civili, 14, Napoli: Edizioni Scientifiche Italiane, 2015.

PERLINGIERI, Pietro. "Complessità e unitarietà dell'ordinamento giuridico vigente", in Rassegna di diritto civile, vol. 1/05, Napoli: Edizioni Scientifiche Italiane, 2005.

Perfis do direito civil. Rio de Janeiro: Renovar, 2002.

Janeiro: Renovar, 2008. 
RODOTÀ, Stefano. "Ideologia e tecniche della riforma del diritto civile", in Rivista di diritto commerciale, I, 1967.

SANTOS, Boaventura; Marques, Maria Manuel Leitão; Pedroso, João. Os Tribunais nas Sociedades Contemporâneas. Revista Brasileira de Ciências Sociais (ANPOCS). RBCS 30, 1996. Disponível em: http://www.anpocs.org.br/portal/publicacoes/rbcs 00 30/rbcs30 07.htm.

SARMENTO, Daniel. "Ubiquidade Constitucional: Os Dois Lados da Moeda", in A Constitucionalização do Direito: Fundamentos Teóricos e Aplicações Específicas, coord. Cláudio Pereira de Souza Neto; Daniel Sarmento, Rio de Janeiro: Lumen Juris, 2007.

Por um constitucionalismo inclusivo: história constitucional brasileira, teoria da Constituição e direitos fundamentais, Rio de Janeiro: Lumen Juris, 2010.

SCHREIBER, Anderson. Novos paradigmas da responsabilidade civil, Rio de Janeiro: Renovar, 2007.

; KONDER, Carlos Nelson. Uma agenda para o direito civil-constitucional, in Revista Brasileira de Direito Civil - RBDCivil, vol. 10, 2016, p. 16. Disponível em: https://www.ibdcivil. org.br/image/data/revista/volume10/rbdcivil_vol_10_02_doutrina-nacional_uma-agenda.pdf. Acesso: 3.1.2017.

STRECK, Lenio Luiz. "O papel da constituição dirigente na batalha contra decisionismos e arbitrariedades interpretativas", in Jacinto Nelson de Miranda Coutinho, Jose Luis Bolzan de Morais, Lenio Luiz Streck (org.), Estudos Constitucionais, Rio de Janeiro: Renovar, 2007.

TEPEDINO, Gustavo. "A Constitucionalização do Novo Código Civil", Editorial, Revista Trimestral de Direito Civil, vol. 15, Rio de Janeiro, Padma, jul-set/2003.

A disciplina civil-constitucional das relações familiares. In: Temas de Direito Civil, t. I. Rio de Janeiro: Renovar, 2008.

. "A estranha revolta dos fatos contra o intérprete", Editorial, in Revista trimestral de direito civil, v. 31, jul.-set./2007.

- "Premissas Metodológicas para a Constitucionalização do Direito Civil", in Temas de Direito Civil, t. I, Rio de Janeiro: Renovar, 2008a.

. "O ocaso da subsunção", Editorial, in Revista trimestral de direito civil, v. 34, abr.-jun./2008b.

"Normas constitucionais e direito civil na construção unitária do ordenamento", in Temas de direito civil, t. 3, Rio de Janeiro: Renovar, 2009.

; BODIN DE MORAES, Maria Celina; BARBOZA, Heloisa Helena. Código Civil interpretado conforme a Constituição da República, v. II, Rio de Janeiro: Renovar, 2012. 
"Livro (eletrônico) e o perfil funcional dos bens jurídicos na experiência brasileira", in Dário Moreira Vicente; José Alberto Coelho Vieira; Sofia de Vasconcelos Casimiro; Ana Maria Pereira da Silva (Org.), Estudos de Direito Intelectual em homenagem ao Prof. Doutor José de Oliveira Ascensão, Coimbra: Almedina, 2015.

VIANA, Iasna Chaves; VIANA, Emílio de Medeiros. Do ativismo ao protagonismo judicial: por uma atuação transformadora na seara ambiental, in Revista de Direito e Sustentabilidade, vol. 2, n. 2, Jul/Dez.2016. 